\section{Travel to India prevented}

Rehovot

A DOZEN Israeli scientists who had planned to attend last week's seventh International Biotechnology Symposium in New Delhi did not do so because of difficulties placed in the way of their obtaining visas.

Most of them gave up months ago, when the delaying tactics of the organizing committee, headed by Professor T. K.Ghose of the Indian Institute of Technology, discouraged them from carrying on their efforts to attend the meeting. But two scientists who were to make presentations in Delhi - Professor Jonathan Gressel of the Weizmann Institute and Dr Stefen Rokem of the Hebrew University - kept trying to get there until the departure of the last flight before the symposium.

Gressel first wrote to the Indian organizers on 21 March 1983, requesting that they send him application forms for a visa because there is no Indian mission in Israel. Five months later, Dr S. Chand advised him that the organizers had arranged "for the concerned authorities to provide a landing permit' ' on his arrival in India. But

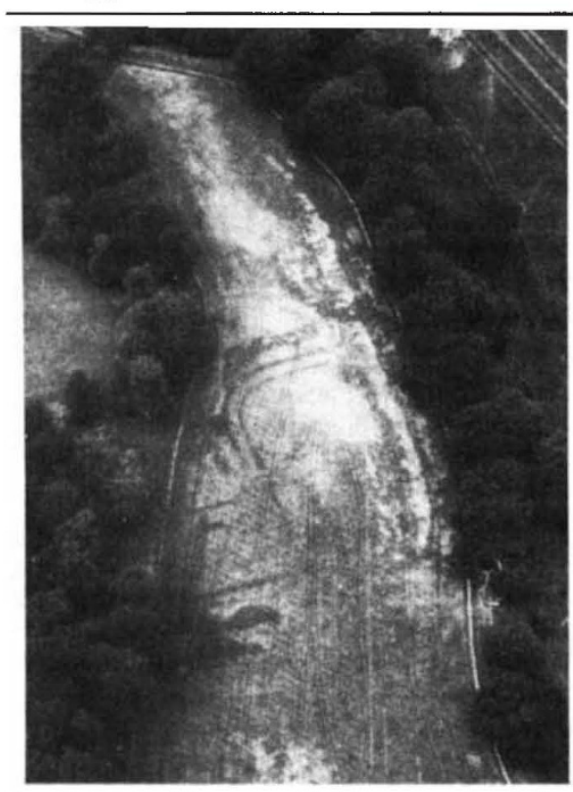

A NEWLY discovered Roman fort in Scotland, one of three revealed by aerial photography during the exceptionally dry summer of 1983. The fort is on the South Esk immediately to the north-east of Kirriemuir, near the castle of Inverquharity, and was built there in the Flavian period, probably by Julius Agricola who, as governer of Britain from AD 83-87, instigated a campaign to contain the Caledonian tribes. For the Royal Commission on the Ancient and Historical Monuments of Scotland, 1983 was a vintage year, with the discovery of new examples of 5,000 year-old long timber halls, whole cemeteries of burial cairns and Iron Age villages, in addition to the forts.
Alitalia, which operates the only scheduled air service between Israel and India, informed Gressel that he could not board one of their planes bound for India on the basis of such a letter without details about the visa.

This should have been simple to arrange because according to Alitalia, the Indian authorities routinely provide such details where ordinary Israeli tourists are concerned. In any case, Gressel was finally informed on 21 January 1984 that he would have to go to the Indian Embassy in Rome for a visa. This he refused to do because it was contrary to the original promise, would cost him US $\$ 200$ more for an additional stopover and, as he cabled Chand, "the Indian embassies concerned usually claimed to have no record of their request"'.

This is only one of many instances where Israeli researchers have been prevented from attending international meetings in India, but no less troubling, says Dr Baruch Eyal, head of the Division of International Scientific Relations in the Israel National Council for Research and Development, is the fact that many Indian scientists invited to take part in meetings in Israel were prevented by their government from doing so.

Meanwhile, Professor Gressel and Dr Rokem are waiting for some action - even if only after the fact - from Professor $\mathbf{H}$. G.Schlegel, chairman of the International Committee on Economic and Applied Microbiology, a sponsor of the symposium. Nechemia Meyers
UK science Declining and parasitic

SIR Hermann Bondi, chairman of the Natural Environment Research Council, warned this week that British science is in decline and that without substantial transfers of resources British environmental scientists will be unable to play an international role. Sir Hermann was thankful that the government had maintained a level science budget within its overall public expenditure policy. But he pointed out that many of Britain's competitors are increasing their capabilities while British science "is standing still on an escalator that is going down".

Sir Hermann argued that cooperation betweeen ships and satellites is essential for the future development of marine research. But, he said, at present there is no money for oceanographers, geologists or ecologists to contribute instrumentation for satellites. All they can do is to analyse information from others' instruments; and "I do not believe that a situation where the scientist depends on the kindness of others is one that is tenable for much longer".

The National Environment Research Council was recently told by a House of Lords Select Committee formally to liaise with the Science and Engineering Research Council on basic research. Some joint projects concerned with remote sensing (see Nature 16 February, p.586) have been in difficulties because of questions about areas of responsibility - and, of course, financial support.

\title{
Nuclear waste rules undecided
}

DeLegates at the London Dumping Covention last week failed to reach a decision on whether the "emplacement" of high-level radioactive wastes under the sea bed comes within its purview.

The issue has become controversial because it is claimed that recent research shows that loading wastes into torpedoes that would penetrate deep beneath the sea bed is at least feasible. But disposal at sea of high-level waste is specifically outlawed by the convention: hence the legal argument which occupied a good part of last week over whether the sea bed includes the earth below the sea bed. Nations which are producing high-level wastes figured prominently among those who held that subsea bed emplacement is outside the terms of the convention, while Spain and some Scanadinavian countries were notably inclined to the opposite view. The timehonoured solution eventually reached was that a decision should be put off until the convention meets again next year, when pollution by plastics will also be considered.

A year ago, the convention adopted a resolution calling for a temporary halt to dumping of all radioactive wastes until such time as the consequences have been fully explored by a scientific working group, and since then the legal niceties of the question have been scrutinized. Last week it was eventually agreed that the group would be drawn from a panel of impartial scientfic experts drawn up by the International Council of Scientific Unions. The group's recommendations will be made and examined by representatives of the 53 contracting parties to the convention before next year's meeting. As this is likely, in the words of the convention, to be an "onerous task", next year's meeting has been postponed by six months until August 1985. This means, incidentally, that the moratorium on even low-level dumping is also effectively extended, a fact which caused some joy to environmental groups, Britain is opposed to, and has never recognized, the moratorium but the matter has become somewhat academic since industrial action by the National Union of Seamen has prevented Britain's annual dump taking place.
Tim Beardsley 